\title{
WILBUR WRIGHT
}

\author{
Gold Medallist of the Society \\ BY GRIFFITH BREWER, A.F.Ä̈.S.
}

THE present generation will never completely realise the magnitude of the loss to Aviation caused by the death of Wilbur Wright, and yet it requires but a moment's thought to recognise that his name will live until all histories are obliterated, for with his brother Orville, he accomplished the dream of ages, which men of acknowledged science had become in the habit of first attempting to accomplish, and then alleging the feat to be amongst the unattainable.

There are only three ways of getting from one place to another on this earth ; one is on land, the next is on water, and the third is now through the air. Certainly it was possible to travel in the air to destinations settled by the caprice of the wind, but to do the same as the birds, and travel from one place to another, had never been possible until Wilbur and Orville Wright accomplished mechanical flight in 1903. So great was this achievement, that when Wilbur Wright came to France to show how this thing could be done, the doubters came from all over the world to see with their own eyes the achievement of the impossible.

In August, 1908, I went to Le Mans to see with my own eyes what I, like others, had hitherto doubted, and when the flying was over for the day and the machine had been put back into its shed, Mr. Wright invited me to dine with him at the little Inn, where Madam Pollet served a plain, well-cooked meal in the little sanded kitchen.

I found Wilbur Wright quite open about his work ; there was no air of mystery or cloaking the achievement of flight with artificial embellishments. Just the simple story of two brothers who had always played together and worked together, and one whose health required constant out-door exercise. At first they made a glider, which not being built upon books, had none of the difficulties enumerated in them, but had others not previously hinted at: and he told how in their holidays which grew longer as their work time grew less, they gained more experience in the art of gliding until they decided on the details of the power-driven machine. And as he told me of the fun they had had at Kitty Hawk with the hot wind blowing on the little tin shed and the thrills enjoyed in the first flights, I realised what lucky brothers they were, to have been blessed with the necessary intelligence, perseverance and love of roughing it, to make such glorious holidays brimful of recreation and enjoyment and yet so useful to mankind. Few know how the experiments were nearly abandoned on some occasions, and how their rival flyers the mosquitoes combined together in their millions to prevent the invasion of their element by man. How many resolutions to pack up and go home to-morrow were made in the night when those tiny insects, which in their myriads blackened the walls of the shed, succeeded in entering the blankets in which the brothers rolled themselves in spite of a night temperature of $90^{\circ}$. Fortunately the tortures of the night were forgotten in the enthusiasm of the day, and so they persevered and robbed the birds of their monopoly.

Many of my early meetings with Wilbur Wright were associated with the late Hon. C. S. Rolls. It was in August, 1908, when Rolls found other engagements prevented his taking part in the Gordon Bennett Balloon Race from Berlin, that he asked me to dine with him and talk over the details of my racing in his stead. He had just returned from Paris, and I was leaving for Paris that same evening, and after we had talked balloons and arranged for Mr. McClean to act as my aid in the race, he turned to me and said, "Why are you going to Paris?" In reply, I said: "Don't tell anyone, but I'm going on to Le Mans to see Wilbur Wright." "Well, don't say anything," Rolls replied, "but I've just come back from there." He then gave me some local directions about how to get to the Champ d'Auvours and where to stay at Le Mans. Afterwards I always stayed at the little Inn near the railway, because then I could be out early if the weather were fine, and in this way I saw many flights. I should otherwise have missed.

The simple life had great attractions for Wilbur Wright. A piece of stout canvas nailed between two pieces of $2 \mathrm{in}$. by $3 \mathrm{in}$. wood supported at their ends on the rafters of the shed containing the machine, formed the bed on which he slept, and often at five 


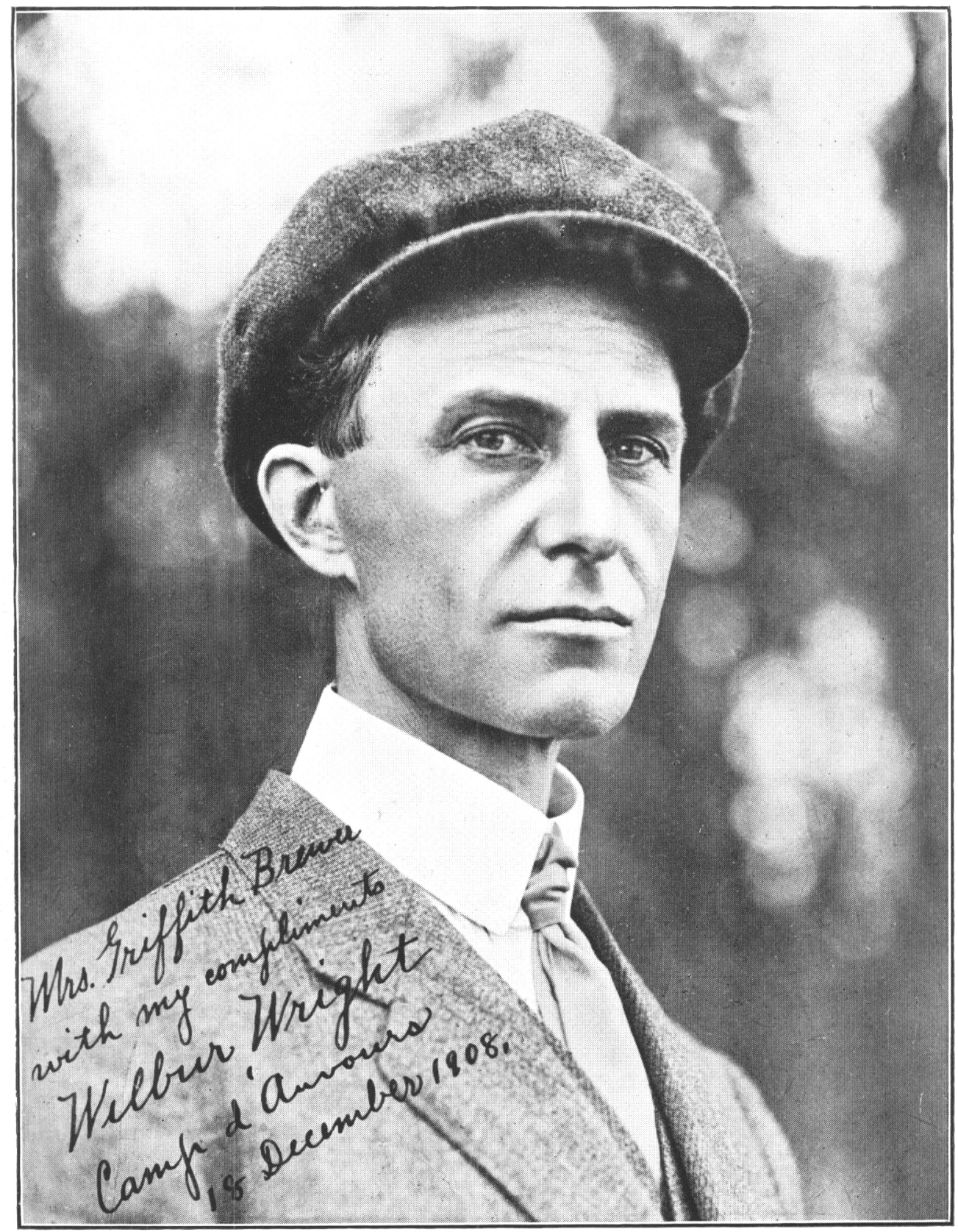

Born April 16, 1867-Died May 30, 1912 
in the sparkling September mornings he was to be seen taking an early cold water wash while the water for the coffee was on the boil. The machine was always his first care, for it was the only machine available and it served for all the flights of those last four eventful months of the year 1908.

The same shed, which by the by was too small to take the machine until the rudder had been folded back, served as his office as well as his bedroom, and as may be well imagined, the popular interest in those early flights attracted a large and in some cases unwelcome correspondence. He had no secretary to look after his letters, and most of his time being taken up with the machine, flying, and answering questions, correspondence could only have very limited attention. The most important letters were attended to at the time, and the remainder were placec in the pile to be answered when time permitted. Many persons who wrote did not seem to realise that Wilbur was one of the hardest worked men, who could not spare time to gratify the idle curiosity of the thousands who were naturally interested.

Some weeks later, just before the Gordon Bennett Race in Berlin, I came again to Le Mans in the hope of having a flight. Mr. Rolls, Mr. Butler and Major Baden-Powell were also there, all with the same hope in their minds. We were so infected with the flying fever, that we were tumbling over each other in the hope of getting the first invitation, and this hope was perhaps intensified by the knowledge that up to that time no Englishman had yet flown. Poor Rolls was torn by two anxieties, one to be given the first flight, and the other to get me off to Berlin so that I should not be too late to compete as his substitute in the Gordon Bennett Race, and the latter fear predominated to such an extent, that he most unselfishly suggested to Wilbur that I should go up first. Whether this turned the balance in my favour or not I cannot say, but after making other trial flights Wilbur came to me and asked if I was ready, so I took my place between him and the engine, and we were launched off the rail and made a three mile flight round the ground. It is somewhat late now to describe the sensation of flying which so many thousands have since experienced, but a first flight like this must be unique. I remember wondering whether we should really rise from the rail, and then a feeling of elation when the grass slipped away backwards and downwards and the machine seemed to be sitting on nothing. There was no sense of travelling except by the appearance of the earth moving backwards, and on looking upwards it seemed that we were on a frame structure in a high wind, but without the sense of movement inherent in all other vehicles which are supported below on wheels or on water. In spite of knowing the theory of banking on a turn, I remember marvelling at the machine not slipping in wards when inclined to such an angle. I am afraid, however, that my keenness of observation of the flight sensations was stifled by my greater interest in the man than in the doings of the machine, and the predominant sense was one of wonder that the same man could calmly invent such a mechanism and yet fly it with such consummate skill. Mr. Rolls made his first flight immediately afterwards, then Mr. Butler, and later in the day Major Baden-Powell.

In November of the same year I introduced a party of Englishmen to Wilbur Wright, viz., Mr. Roger Wallace, K.C., Lord Royston, Professor Huntington, Mr. McClean, and Mr. Eustace Short. Having accidentally missed Wilbur in Le Mans, we returned to Paris, where we met him next day, and he entertained us to lunch. Afterwards Mr. Wallace, Professor Huntington, Mr. McClean and Mr. Short returned to Le Mans and were given short flights the following morning, as a compensation for their fruitless journey to Le Mans the previous day. Wilbur never took a fee for any of these passenger flights, and when it is remembered that many people were willing to pay hundreds of pounds for a flight in those early days, these four special flights were a favour of no small character.

During the last three months of the year 1908, when Wilbur beat all his own records and set up new world's records for duration, distance, and altitude, scientists and notabilities came to Le Mans from all parts of the world, many of the former affirming that they had always believed in the flights made by the Wrights in America in 1903 to 1905 . Others made numerous suggestions of how to simplify. what they regarded as a clumsy apparatus. One distinguished scientist, after looking at the machine for some time, asked Wilbur if he would allow him to measure the camber of the planes, because this would enable him to estimate the 
length of the undulations followed by the machine in flight. Having been given permission he made a complicated series of calculations and then asked if the length he mentioned was the length of the waves of flight. In reply, Wilbur said that the length of wave was not correct, because the machine flew straight, and not on an undulating path. The scientist was astonished, and replied, "Impossible," to which Wilbur, ever a pioneer in all he did, replied, "Wait and see." Surely enough the scientist did see the machine make a straight flight soon afterwards, and it is to be hoped that by this time he has forgiven it refusing to follow the laws of the air, which were regarded as infallible at that time.

In January, 1909, Wilbur Wright went to Pau to continue his experiments and to teach the first three pupils how to fly. I was prevented from going by having to undergo an operation, but as soon as I was convalescent early in February, Mr. Rolls gave me a seat in his car and with Mr. Massac Buist we went leisurely across France to Pau, where by that time Wilbur had been joined by his brother Orville and his sister, Miss Katherine Wright. I think it was at this time that I more fully realised how kind and thoughtful these three Americans were, for although kings and world-known men were continually there to see the flights, one or other of those three always found some time to stay by me as I lay on my rug on the flying ground. This was the first opportunity I had had of hearing the two brothers discuss the machine and its doings, and it soon became obvious how suited they were to thrash out the many intricate problems which continually arose. Nothing was ever taken for granted until proved by themselves in actual practice; all the hitherto recognised rules of wind and air currents were forgotten and replaced by new tables in writing contained in little pocket books; and in the arguments, if one brother took one view, the other brother took the opposite view as a matter of course, and the subject was thrashed to pieces until a mutually acceptable result remained. I have often been asked since these pioneer days, "Tell me, Brewer, who was really the originator of those two ?" In reply, I used first to say, "I think it was mostly Wilbur," and later, when I came to know Orville better, I said "The thing could not have been done without Orville." Now when asked, I find I have to say, "I don't know," and I feel the more I think of it that it was only the wonderful combination of these two brothers who devoted their lives together for this common object, that made the discovery of the art of flying possible.

Early in 1909 an American millionaire, with a confidence born of unlimited dollars, came to Pau intending to make a flight with Wilbur, and talking to one of the "English Bunch," he said he had come for that purpose. The Englishman expressed surprise, because as he said he understood Wilbur was not taking passengers, to which the American replied, "Oh! I daresay that can be arranged." "Well," said the Englishman, "I should like to be around when you do the arranging, just to see how it's done." What reply he got to his suggestion will never be known, but he left Pau without having had a ride in the air.

One day we were working together in the little office at $\mathrm{Pau}$, when a card was brought in bearing the name of a lady of title. "That lady, who is an entire stranger," said Wilbur, " wrote saying she was coming here next week, and so as she had settled to come, there was no need for me to reply. Then she telegraphed yesterday to say she would come to-day, and as she had also settled this definitely, there was no necessity for me to reply to this wire. Now she is out in the ground and wants to waste my time without any kind of excuse." With that, the card joined the rest of the correspondence in suspense, and we resumed our work. Later, Wilbur went out and made a pretty flight, which was no doubt viewed by the lady along with the other spectators. I wondered at the time whether it would have been possible for him to gratify everyone, but it was evident after consideration of the circumstances that it would not have been feasible to do so. I also wondered whether the lady herself would be guilty of leaving a letter addressed to her unanswered. I have since been able to satisfy this last speculation, by recently writing to ask her for a small subscription to the Wilbur Wright Memorial Fund, to which letter I have received no reply.

When in Paris, just before the visit of Wilbur and Orville Wright to England, when they received the gold medals of the Aero Club and the Aeronautical Society, and were fêted by both those bodies, I was describing some of the people to Wilbur whom he would meet in England. Of one I said that he would at once recognise him as being the ugliest 
man at the Aeronautical Society, and my rudeness was quietly reproved by his replying that the member of the Society would lose that distinction on this occasion because, as he said, "There will then be a pair of us."

Discussing happiness one day, Wilbur remarked that most enjoyment in life consisted of relief from discomfort. To try to be always comfortable and happy was therefore a mistake, for if one succeeded life became unbearably monotonous.

Discussing cricket as compared with baseball, Wilbur described most vividly the excited enthusiasm raised by the American game. His own words in a letter to me of the 9th July last year, from Berlin, make an interesting comparison between German cricket and Ameriran baseball :-

"I would I could go with you-but it seems that it is impossible. A pleasant voyage to you.

"To-day I took a stroll down to Tempelhofen field, where Orville did his flying in Berlin. I was rather surprised to find three or four games of cricket going on in different parts of the field. You will wonder what cricket looks like and sounds like in Dutch, but as I have never really seen a game in England, I do not know how to compare it with the genuine article. While you are in America get Orville to take you to see a baseball game. The conduct of the crowd will interest you immensely whether the game does or not. A baseball game at a school for deaf mutes would be noisy compared with this German crowd at a cricket game."

Ever since I have enjoyed Wilbur's friendship, I have found difficulty in writing the articles on aeronautical and atmospheric subjects that $I$ have been in the habit of doing occasionally for some twenty years past. The reason for this is not that he has in any way abstracted the little knowledge I formerly possessed, but his lucid arguments and unanswerable information gradually altered most of my views, and whenever I have since tried to work out some problem or theory independently, I have found myself adopting and arguing some theory of Wilbur's, forgotten for the moment, but recognised when committed to paper. At first I used to mention Wilbur's name in acknowledgment, but after a time I found I had to mention him always, so I ceased to give him credit. This latter course seemed preferable as involving myself alone, and my confession now that I owe everything to him may atone for these omissions.

Describing an adventure by Parmelee on the Mexican border during the last civil war, Wilbur wrote in April, 1911, saying:-

"They were flying over a country where for a hundred miles there was no landingplace except the Rio Grande River. The cut-off cord got wet and shrunk so that it pulled the cut-off handle till one cylinder stopped exploding, so they gradually began to sink towards the river. Parmelee tried to make Lieut. Foulois understand what the trouble was, but could not succeed until too late. Finally just as they were touching the water Foulois "caught on " and pushed the lever back, but the effect was to turn the machine downward a little and make it dive for the bottom of the river. The next thing Parmelee knew he was sitting on the rocks at the bottom of the river with eighteen inches of water over his head. He lost no time in seeking higher atmosphere. Foulois' head soon appeared above water also, but as the lieutenant is only $5 \mathrm{ft} .1 \mathrm{in}$. tall, and the water was over $4 \mathrm{ft}$. deep., there was a margin of only about an inch under his chin. The banks were so steep that they had to wade down stream a quarter of a mile before going ashore. The machine was not much injured, and is all right again.

"It was a foolish trip undertaken without proper precautions, and while the cause of the accident was ridiculously trifling, the results might have been very serious."

Wilbur Wright was never an advocate of excessive speed, and in a letter of extraordinary technical interest to the pilot of the Wright machine in the Gordon Bennett of 1911, he said:-

"I had seen from the newspapers that you had finished the course and escaped without any smash-up. These were the only things I really cared about in the race. A matter of a few miles speed more or less was not a serious matter. Your troubles would be amusing if they were not so heart-breaking while they were going on. 
"You are quite right in thinking that at high speeds the head resistances become very important, but I see that you are fooled on several points. If you stop to figure up you will find that 80 miles an hour is the speed a falling body attains after a fall of 256 feet. While 40 miles an hour is attained in less than 60 feet. So that a Nieuport cut off at 80 miles and landing at 40 has used up the equivalent of $200 \mathrm{ft}$. in addition to its actual drop. It ought therefore to go $6 \times 230=1380 \mathrm{ft}$. before landing, if cut off at $30 \mathrm{ft}$. height. Your speed the day your motor struck with you was probably not more than 45 miles so you had no surplus energy. A machine with two propellers naturally does not glide as far as with a single propeller.

"Comte de Lambert tells me that the Nieuport motor is $135 \times 145$ and runs 1400 . Now $\frac{135^{2} \times 2 \times 145}{111^{2} \times 4 \times 101}$ is in the proportion $\frac{528}{497}$ so that it is a sixteenth larger than our 4-cylinder motor. The speed of the Nieuport with 100 h.p. motor was about what Brookins had with not over 70 h.p. last year. We built that machine to prove that the talk about the speed advantages of the monoplane and the fore and aft arrangements was largely rot. It was faster than any of the 100 h.p. monoplanes of its time.

"I have written a letter to the New York Herald proposing that in 1912 no motor having a total piston area of more than $665 \mathrm{sq}$. centimetres and 8,000 cubic centimetres displacement be allowed in the Gordon Bennett. This is the size of the $50 \mathrm{~h} . \mathrm{p}$. Gnome. If the proposition is accepted we will show them whether the biplane is slower than the monoplane. If they insist on motors of any size the race will not interest us, as we do not care to fly over 100 miles an hour ourselves or put our men on such a job."

The following advice may be useful to young members of this Society :-

"It is always a serious thing to land with a strong wind on the back, because as soon as the speed is as little or less than that of the wind, the pressure on the tail tends to turn the machine over instead of preventing it.

"Therefore I would strongly advise with the little machine, that you always keep sufficient height when going with the wind so that you can turn and land facing it. Young birds often get rolled head over heels by making the mistake of landing with the wind. Old birds never attempt it. It will be well for us to follow their example as far as possible."

It is usual with a genius, for the dominant subject to overshadow all others greatly to their detriment. Wilbur did not suffer in this respect. On subjects of which I had some knowledge he could always add some information, and even in my special work I learnt some points from him. Anyone seeking an example of a clear Patent Specification should read Wright Brothers' original specification No. 6732/04. I cannot say which of the two brothers wrote it, because as I have already pointed out, all their work was so combined, but I can assure the members of this Society that the wording is that of the inventors, and only minor alterations are by the patent attorney. Remembering that this subject was unknown and not taken seriously by practical men at the time, the language is wonderfully clear and the features of the invention are marvellously explained and yet in simple language. Nowadays complicated formulæ are considered necessary to explain inventions involving but a fraction of the ingenuity displayed in this master Patent.

Discussing the relative costs of Patent actions in America and in England, Wilbur gave me a humorous example of a Patent Attorney's quotation of the probable costs that would be incurred. On the patentee asking how much it would cost to bring an action for infringement against an alleged infringer, the attorney replied by putting the question, "Well, how much have you got?" On the inventor giving an estimate of his realisable assets, the lawyer replied: "Well, that's just the amount the action will cost you." Unfortunately there is a great deal of truth in this fable, and he is a lucky inventor who invents a mechanism that is useful enough to be profitable, but not so exceptionally valuable as to tempt all the world to infringe and to belittle the invention in order to excuse themselves. It would be a poor policy if inventors were refused a just reward for 
their ingenuity in order to facilitate the free use of their work by all, for the withdrawing of capital and the diverting of intellect from the field of invention into other more secure channels would then result.

When an inventor makes a great invention, he usually sells the foreign rights to the highest bidder. The Wright Brothers had several excellent offers for the British rights, but they did not accept any of these, because they regarded their invention as one carrying moral obligations, and not simply as a negotiable property. They felt it their duty to see that if a company were formed in England, the invention should not be exploited on popular company lines at the risk of the shareholders being left with shares and experience only, in exchange for their money, and as they were unable to withdraw sufficient of their time from their experiments and undertakings in America and on the Continent, they kept the British Patents in their own hands, and have hitherto reaped little profit so far as England is concerned.

This spirit of moderation characterised all their actions. In France rival owners and representatives of other machine makers were welcomed on the flying ground, the machine explained, and in some cases flights given to them. But all their liberality could not save them from the resentment many cherished for the crime of being the first to fly, and so preventing each of those others from being the first if the Wrights had not existed. Fifty years ago men were still on the brink of flight, and with just as much reason, and there is no more justification to expect that these latter men would ever have stepped over the dividing line which their fellow workers of long ago failed to do.

The resentment of this jealousy was afterwards supplemented by the fear of the Wright Brothers endeavouring to collect the tribute which the Crown recognises as the reward of those who give to the nation a new industry, and instead of facing this question in a fair manner many have striven to accuse and excuse, although no application for royalty nor threat of an action for infringement has ever been made against any manu. facturer or flyer in Great Britain.

After their return home the Wright Company was formed to work the invention in America, and the companies that had been formed in France and Germany were left to work out their own salvation and to manufacture their own machines. Unfortunately the companies on the Continent were ambitious and missed the guiding hand of the inventors, and many so-called improvements were also introduced into the Continental machines, with the result that while the American company has prospered, the European companies have not progressed. The enthusiasm of this visit to Europe was followed by the natural reaction on the departure of the brothers for America, and the subsequent law actions to enforce the French and German Patents were resented by all who desired to use the invention, but not to pay for it. A campaign of belittlement of the Wrights' invention followed, one claim of anticipation being raised after another, only to be destroyed on investigation being made into its merits. This unfair resistance to a fair acknowledgment of their Patent rights threw a considerable and worrying work on Wilbur Wright, who was thus drawn against his inclinations from his natural work of experimenting and flying, and his health suffered at times from this uncongenial work. A year before his death I persuaded him to throw up this arduous work at Paris and come to England for a change, and some weeks at Eastchurch leading the simple life and working at Mr. Ogilvie's machine enabled us to send him back to the Continent completely recovered. He was in Boston on similar distasteful law work when he contracted his fatal illness, and if he had not been handicapped by lack of out-door life he would probably have pulled through. As it was, he fought for weeks against the relentless microbe that knew no mercy, and he died as he had lived, a fighter to the end undeterred by heavy odds against him.

Although an American, Wilbur Wright was of English descent, and the son of a family of pioneers. One of the Wrights was one of the early settlers at Springfield, Mass., having emigrated from Kelvedon Hall, Essex, in 1636. A later ancestor moved further West, and was one of the first to cut into the forest and found the city of Dayton, Ohis, and Bishop Wright, the father of Wilbur and Orville, has done pioneer work for the Church, whilst a further brother, evidently imbued with the same pioneer instinct, moved out West to Arkansas before his two brothers became famous. 